\title{
A COMPARATIVE ANALYSIS OF PARTICIPATORY ERGONOMICS PROGRAMS IN U.S. AND JAPAN MANUFACTURING PLANTS
}

\author{
Jeffrey K. Liker \\ The University of Michigan, Center for Ergonomics, Industrial and Operations Engineering, \\ Ann Arbor, MI, 48109 (U.S.A.) \\ Mitsuo Nagamachi \\ Hiroshima University, Dept. of Industrial and Systems Engineering, Shitami Saijo-cho, \\ Higashi Hiroshima-City 724 (Japan) \\ and Yair R. Lifshitz \\ The University of Michigan, Center for Ergonomics, Industrial and Operations Engineering, \\ Ann Arbor, MI 48109 (U.S.A.)
}

(Received July 18, 1988; accepted September 1, 1988)

\begin{abstract}
The use of a participative approach to ergonomics is growing in countries throughout the world. This paper compares and contrasts Participatory Ergonomics programs in two U.S. and two Japanese manufacturing plants. All four programs focused on the redesign of repetitive manufacturing jobs to reduce physical stress on workers. In all four cases, this traditional ergonomics concern was addressed in a non-traditional way-involving broad participation of many manufacturing functions who worked together as an ergonomics team and direct input from operators whose jobs were redesigned.

The participatory ergonomics programs were successful in making significant numbers of job changes in both countries. A comparison of the ergonomics programs across countries revealed some significant differences in structure and process. An overarching difference was in how participation was managed. In the Japan cases, participation was a carefully controlled process by which upper management and staff specialists worked through first-line supervisors to get input from workers meeting in quality (or safety) circles. In the U.S., multi-functional and multi-level task forces (including union and worker representatives) were formed and operators were invited to meetings to give input. The U.S. plants gave the task force a great deal of autonomy and virtually all decisions were group decisions. The differences suggest that effective participatory ergonomics programs can take many forms. The best program for any particular plants in differing countries depends on their own unique history, structure, and culture.
\end{abstract}




\section{INTRODUCTION}

The use of a participative approach to ergonomics is growing in countries throughout the world (Imada, in press). This paper compares and contrasts Participatory Ergonomics (P.E.) programs in two U.S. and two Japanese manufacturing plants. All four P.E. programs focused on the redesign of repetitive manufacturing jobs to reduce physical stress on workers through reductions in fatigue, improvements in working posture, and elimination of other risk factors associated with cumulative trauma disorders and low back pain (Chaffin and Baker, 1970; Armstrong et al., 1986; Nagamachi, 1983; Garg et al. 1978). In all four cases, this traditional ergonomics concern was addressed in a non-traditional way-involving broad participation of many manufacturing functions who worked together as an ergonomics team and direct input from operators whose jobs were redesigned.

The use of small group problem-solving methods has a long tradition in the United States, going back at least to the famous Hawthorne experiments of the 1930s. In the 1940s, Kurt Lewin and his associates at the University of Michigan further developed concepts of group dynamics as applied to practical problem solving and experimented with these methods in industry (French and Bell, 1987). However, the Japanese are given credit for successfully disseminating group problem-solving methods on a broad scale in the form of quality circles (Cole, 1979). U.S. companies, witnessing the tremendous success of the Japanese in mobilizing their workforce for productivity and quality, began to organize "Americanized" versions of quality circles. While the Japanese version began with the goal of improving quality through statistical quality control (Juran, 1967), U.S. plants had the goal of improving human resource utilization and labor relations by focusing on group dynamics and motivational aspects of small group activities. Participative management, quality of worklife, and employee involvement are American terms which define small groups activities as part of a new human resource management philosophy (Kanter, 1983).

By several measures, the Japanese quality circles have far surpassed their U.S. counterparts. In a study comparing 110 Japanese-factories to 110
U.S. factories, Hull et al. (1988) find the Japanese factories were more likely to have quality circles ( $76 \%$ in Japan compared to $18 \%$ in the U.S.) and the rate of employee suggestions is far greater in Japan (mean yearly suggestion rate of 11 per employee in Japan as compared to 0.1 per employee in the U.S.). Among plants that had quality circles, an average of $72 \%$ of the workers participated in Japanese plants, while only 19\% participated in the U.S. *

Despite the widespread use of small group activities in both the U.S. and Japan, the use of ergonomics to reduce injuries, illness, and fatigue has not been a central mission of these programs. The underlying philosophy of quality circles is that workers should have responsibility for and directly participate in the continual improvement of their work and therefore the goals and methods of ergonomics would seem to be a natural part of this participative process. However, Ishikawa (1968) in one survey found that $50 \%$ of the Japanese circle activities focus on quality control, $40 \%$ on productivity and cost considerations, and only $10 \%$ on safety and other affairs. While a few companies such as Mitsubishi (one of our four cases) have developed safety circles as an adjunct to quality circles, safety circles typically focus on prevention of accidents and acute trauma rather than the redesign of work to reduce cumulative trauma disorders, low back pain, and fatigue. On the U.S. side, the emphasis on problem-solving groups as part of an egalitarian management philosophy has led to a hands-off management approach in the selection of problems. Groups select their own problems which at least at first focus mainly on improving hygiene factors (e.g., installing soda machines, improving ventilation, reducing noise levels). However, these groups are not trained in ergonomics and hence any ergonomics problems identified are merely incidental.

The case study approach used here provides an in-depth look at structure and process of the ergonomics programs. As Rogers (1983) observes, we

\footnotetext{
* These statistics were collected in 1982 in the U.S. and in 1983 in Japan. We suspect that U.S. companies have made some strides in quality circles since that time, but by no means enough to catch up to the Japanese.
} 
know too little about the variables influencing adoption of innovations at a systems level to conduct large-scale surveys of plants. Nonetheless, the case study approach has its limitations. Our ability to test specific hypotheses is weak, and it is unclear whether the findings generalize to a larger sample of plants. Rather, the purpose is threefold: First, the cases illustrate that a participative approach to ergonomics is viable in both countries and can lead to an impressive number of job improvements. Second, the cases suggest ways in which participatory ergonomics programs adapt to the local structure and culture of the company and national environment. Finally, the approaches taken by these companies provide models of participatory ergonomics which other companies can adapt to their own needs and environment.

\section{MODELS OF PARTICIPATION}

No consensus has yet emerged on the correct definition of participative management. Much of the heated debate between Locke and Sashkin (Sashkin, 1986; Locke et al., 1986) focused on rather subtle differences in definition of the concept. Rather than enter that thorny debate, we will take the view that there are many different models of participation, each with their own merits and weaknesses. Figure 1 represents six models of participation that will be helpful in analyzing the differences between the U.S. and Japanese P.E. programs.

Each of the six models is a unique combination of two dimensions. The column titles across the top represent three modes of participation taken from the Vroom-Yetton model (Vroom and Yet-

\begin{tabular}{|c|c|c|c|}
\hline $\begin{array}{c}\text { Level of } \\
\text { Participation } \\
\text { (Coch \& French, 1948) }\end{array}$ & $\begin{array}{l}\text { Individual } \\
\text { Consultation }\end{array}$ & $\begin{array}{l}\text { Group } \\
\text { Consultation }\end{array}$ & $\begin{array}{c}\text { Group } \\
\text { Consensus }\end{array}$ \\
\hline Representative & I & III & $\mathbf{V}$ \\
\hline Direct & II & IV & VI \\
\hline
\end{tabular}

Fig. 1. Models of worker participation. Note: Shown are six models of worker participation based on combinations of Coch and French's (1948) two levels of participation and Vroom and Yetton's (1973) three modes of participation. ton, 1973).* In the individual consultative model, managers consult their subordinates on an individual basis to get their input, but still make the final decision. In the group consultative models, managers assemble their subordinates in a group meeting and consult the group to get their input and again management makes the decision. In group consensus, managers meet with their subordinates and through discussion as a group achieve consensus on the best decision.

The titles of the rows in Fig. 1 represent the distinction between direct and representative participation in the seminal experiments by Coch and French (1948). Direct participation means each employee participates directly in decisions about their own work. Representative participation means that employee representatives are selected to represent the viewpoints of a large number of workers. Elected union officials are one form of representative participation.

By combining the two dimensions, six models of participation emerge. At the lowest level of participation (Model I) worker representatives give their suggestions on a individual basis to management. In Model II, workers individually give direct input, but management makes the decision. Traditional employee suggestion programs are an example of Model II. At the other extreme, Model VI represents direct participation by all employees via consensus decision-making. If management gives quality circles the autonomy to make decisions and all employees participate, this would examplify Model VI participation.

As we will see below, none of the four P.E. programs fit exactly into any of the six models. However, these models will help clarify differences between the U.S. and Japan programs.

\section{RESEARCH METHODS}

Researchers in the United States and Japan independently worked with manufacturing plants to organize and evaluate pilot participatory ergonomics programs between 1982 and 1987 (Naga-

\footnotetext{
* Vroom also included several modes of autocratic decisionmaking in his model (the manager makes the decision), as well as delegative decision-making (the decision is delegated downward with no management involvement).
} 
machi, in press; Liker et al., in press). The Japanese plants were the Mitsubishi engine plant and the Daikin air conditioning plant. The U.S. plants, an auto stamping plant and an auto assembly plant, were both part of the same manufacturer.

Evaluation methods included independent assessments of risk factors associated with physical stress on jobs in two of the plants before and after changes by ergonomics committees, qualitative observation of meetings and review of minutes, periodic interviews with key participants in the programs, and limited medical surveillance. In 1987, the first author visited the two Japanese companies and interviewed managers and staff members who were key participants in the ergonomics programs.

\section{CASE BACKGROUNDS}

The ergonomics programs in all four plants are atypical in the degree to which ergonomics was linked to employee participation. The programs in all four plants stand out in their countries, and within their own companies in this respect. In fact, each program is viewed by its respective company as a pilot program from which learnings can be disseminated to other plants.

In all four cases, the development of the programs were admittedly influenced by university faculty who strongly advocated that the plants use some form of group problem-solving with worker participation. Nonetheless, the specific participative structure and processes used by the plants were determined by plant management and staff. A brief background on each of the plants provides the context for our analysis.

\section{U.S. auto stamping}

This fifty-year old plant stamps out body parts for several vehicle lines (mainly older vehicles). In 1985, when the ergonomics program began, the plant employed about 2200 hourly workers and 325 salaried employees. By the time the P.E. program was in operation for two years, hourly employment had been reduced to 1500 and another substantial reduction in force was already planned. Throughout this period, quality and productivity were continually improving. A shift from an auto- cratic management style to a more participative approach is believed to be a major reason for the impressive productivity and quality improvements of this plant. Like quality circles, the participative program centered on employee problem solving groups who met weekly for about one hour. More recently, the plant has been shifting to self-directed work teams who meet on a less formal schedule.

The automotive division of which this plant was a part had funded a multi-year university program of basic ergonomics research, training, and consultation. As part of the broader grant, the stamping plant program focused on researching participatory approaches to ergonomics (Liker et al., in press). The stamping plant was selected as the study plant because of the plant manager's strong commitment to ergonomics and the plant's reputation for innovative human resource management programs. After sending a considerable number of managers and professional staff to university training courses sponsored by the division, the plant manager and union leaders agreed to work with the university to set up a more organized, participative approach to ergonomics and allow researchers to evaluate the program. In exchange, a graduate student assigned to collect data on the program's progress would attend all ergonomics meeting, provide technical support, and provide training to the ergonomic's groups. University faculty also provided special ergonomics training in the plant under division sponsorship.

The main purpose of the ergonomics program in this plant was to improve the quality of work life for operators. While productivity might also increase, management emphasized that they felt obligated to provide a safe and healthy workplace and that was the first priority. The program continues to be active as of 1988. Because of the downsizing and cost-cutting programs, the ergonomics program has not been well funded and has had to survive considerable turnover of management, staff, and operators.

\section{U.S. auto assembly}

This plant assembles large luxury automobiles. As of December 1987, the plant employed 3200 hourly workers. Car sales for the plant were strong 
when the ergonomics program started and remained strong as long as the program was tracked. Like the stamping plant, this vehicle assembler has one of the most active employee participation programs in the corporation. Management believes the participative programs are a major reason why the plant enjoys an exceptional quality record and examplary labor relations. The worker participation program started in 1981, and as of $1987,10 \%$ of hourly employees participated in problem solving groups that met weekly for about 1 hour (30 groups of 9-10 people).

The formally structured ergonomics program began in 1986 as a joint union-management program. This plant is part of the same division as stamping and hence covered by the same division-wide ergonomics program. However, unlike the stamping plant, it was not formally selected as a research site. The plant requested assistance in setting up an ergonomics program and a participative approach was suggested as a preferred way of organizing. Union officials and management mutually agreed the participative approach was consistent with the plant's labor-relations philosophy. Like the stamping plant, the assembly plant was provided special training by university faculty and ongoing support from a graduate student in ergonomics.

The main purpose of the ergonomics program was to reduce medical costs, raise productivity, improve quality, and improve the health of operators in the plant. The assembly plant ergonomics program was still active in 1988 and growing steadily.

\section{Daikin air conditioning plant}

The Sakai complex of Daikin makes mid-size air conditioners, primarily for commercial use. This complex in 1987 employed about 700 hourly workers. Sakai is the mid-sized of three Daikin locations in Japan. The complex includes several plants. Sales are strong and quality is high. The complex has a very active quality circles program with participation by virtually $100 \%$ of their hourly workforce. Problem-solving meetings are held monthly.

The ergonomics program was started as a proactive attempt to enable senior workers to perform jobs with a minimum amount of physical stress.
The proportion of workers over forty at Saikai increased from $22 \%$ in 1976 to $49 \%$ in 1985 and is forecasted to reach $52 \%$ by 1990 . The proportion of workers over fifty was 7\% in 1976 and is expected to reach $20 \%$ by 1990 .

Since aging of the workforce is a national concern, the Japanese Department of Labor provided support to fund this innovative pilot program. The support went directly to Daikin who hired Professor Nagamachi as a consultant.

In 1982, the plant's newest line was selected for ergonomic improvements. The line was completely redesigned using ergonomics principles in 1982 and then completely redesigned a second time in 1986 (a second D.O.L. grant was won for the second wave of changes). In addition to ergonomic improvements to most jobs, particularly heavy jobs were automated which reduced the number of workers and increased productivity significantly.* In this paper we focus on the first wave of changes only (which took place between May and August of 1982). As of August 1987 no other lines had been redesigned using ergonomic methods.

\section{Mitsubishi engine plant}

The Mitsubishi complex in Kyoto assembles engines and performs some machining operations (e.g., grinding crankshafts). Mitsubishi prided itself on being a safety conscious company even before the ergonomics project. In addition to quality circles who met monthly, the same groups also meet monthly for one hour as "safety circles." Safety circles are led by the supervisor of an area and virtually $100 \%$ of hourly workers participate in meetings. In many Japanese companies quality circles meet after normal working hours on unpaid time, but at Mitsubishi, the quality and safety circles meet during paid working hours and the line is stopped to hold the meetings (if the line is stopped for other reasons, the circles can have extra meeting time). While Mitsubishi has safety circles throughout their plants, the Kyoto plant

\footnotetext{
* The second wave reduced the number of workers from 60 to 45 , while output increased from 400 to 500 units/day, a $66 \%$ productivity increase. Since half of the workers in the plant are "temporary" workers, the loss of jobs was handled by letting go temporary workers.
} 
was the first to use safety circles to address ergonomic concerns.

In late 1980 , Kyoto management became concerned because workers were reporting high levels of fatigue. In October of 1981, Professor Nagamachi was invited to lecture on ergonomics; his presentation emphasized the relationship between working posture and fatigue. Nagamachi then suggested they organize a steering committee to collect data on working posture. The company set up a steering committee and decided to use their safety circles as the main vehicle for collecting data and suggesting improvements. The program was still active as of August 1987. Throughout that time the focus of the program has been exclusively on working posture.

\section{DESCRIPTIVE COMPARISON OF U.S. AND JAPAN ERGONOMICS PROGRAMS}

\section{Program structure}

The structure of each program provides a snapshot of each Participatory Ergonomics program. We group the two U.S. programs together as they were so similarily structured (see Fig. 2).

\section{U.S. Cases}

The striking similarity between the two programs was partly due to the influence of their outside consultant who suggested various options for program structure. However, all decisions about program structure and membership were made by the plants. For example, each plant decided not to attempt to tie the ergonomics program to their existing employee problem solving groups as employees in these programs have complete autonomy to choose their own projects and ergonomics could not be pushed onto their already full agendas.

Both plants were organized into several autonomous areas, each with their own area manager. They both decided to organize ergonomic groups within areas. In the case of the relatively small stamping plant, two areas covered all of the operations in the plant and thus two groups were organized covering all of the major staff functions in that area with representative hourly operators, a union representative, and engineers assigned to the area as group leaders. The assembly plant chose one area as a pilot and the area managers elected to lead the groups themselves, thus providing a higher level of authority on the committee compared to the stamping plant. Beyond this, the make-up of the ergonomics groups were quite similar in both U.S. plants. In both plants, representative hourly workers were selected by union and management leaders.

The ergonomics groups received several hours of training up front (one half-day at assembly and two half-days at stamping). Thereafter, training became an ongoing effort. Most members went to several day courses offered as part of the division-sponsored program and the graduate student assigned to the plant provided short specialized sessions on particular analysis techniques.

The ergonomics groups met each week for about one hour. Virtually all of the problem-solving and decision-making was in fact done in group meetings. In these meetings they select jobs for analysis, evaluate jobs for physical stressors, design solutions to reduce major stresses detected, and follow-up on implementation of the solutions. Since the groups include engineers, managers of the skilled trades, skilled trades workers, and a representative of the union, most solutions can be implemented without major obstacles.

Both plants had a policy of direct, consultative participation (Model II) to be implemented by inviting the operator (typically from the day shift) and supervisor of the job to at least one meeting to solicit their input. (In fact, ergonomics groups varied in the extent to which they actually followed through on inviting operators and supervisors to meetings. Even when invited, operators and supervisors did not always attend the meetings.)

The ergonomic techniques used to evaluate stress on jobs were a combination of computer software, the NIOSH Work Practices Guide (NIOSH, 1981) and subjective judgements by participants. The evaluations were based on video tapes of the operation. The main computer software used was a 2D static-strength model of manual lifting (Chaffin and Andersson, 1984) and an energy expenditure model (Garg et al., 1978). These were used when deemed necessary to supplement the collective judgements of group mem- 


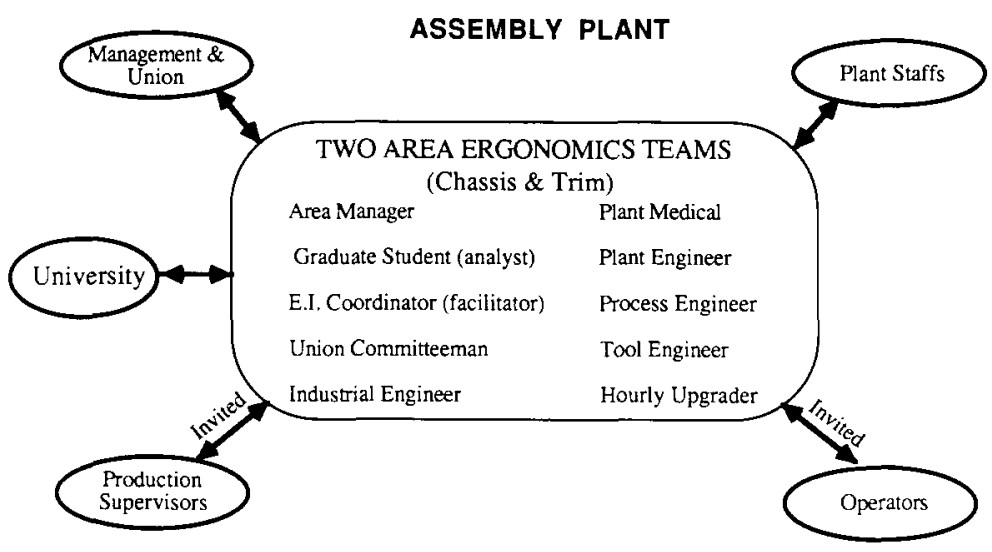

STAMPING PLANT

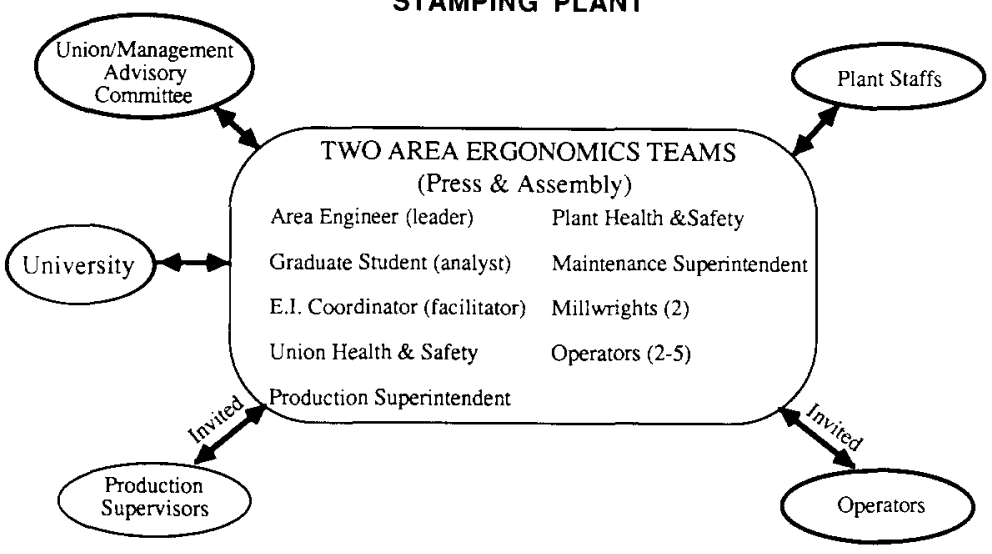

Fig. 2. Program structure in U.S. auto plants.

bers which were guided by checklists designed by each plant for their own use.

\section{Daikin}

This company established a "steering committee," led by the Director of General Affairs, to oversee the ergonomics efforts and make all final decisions, while input was provided by quality circles via the supervisors of each part of the line (see Fig. 3). The steering committee met three times for one-half day each between May and August of 1982 (when the line was changed). The first of these three meetings was devoted mainly to training.

Most of the actual analysis and design took place outside of committee meetings, primarily through the efforts of the general affairs manager working with industrial engineering. This included all specialized analyses and coordination of the program. Supervisors collected the more subjective data (using structured questionnaires and interviews) at quality circle meetings.

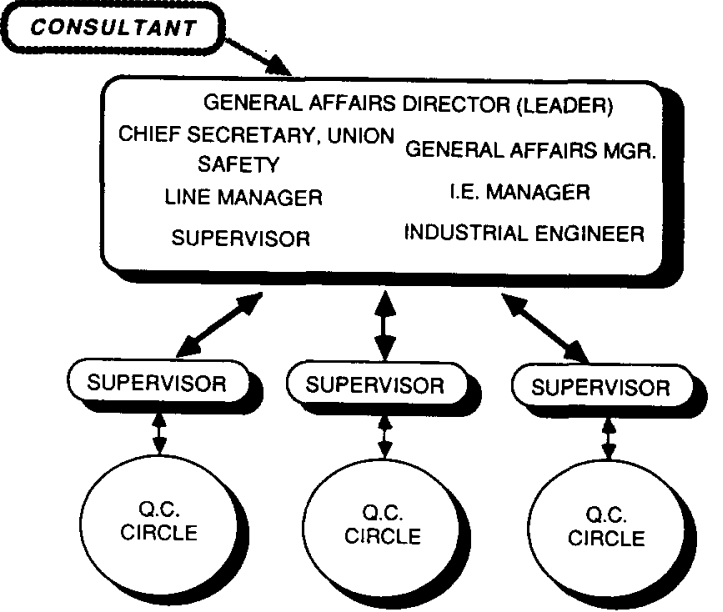

Fig. 3. Daikin ergonomic program structure for air conditioner assembly line. 
Four different methods of data collection were used to evaluate each of the 24 jobs on the line (Nagamachi, 1981, in press): First, quality circle members on each of the 55 jobs filled out a job stress questionnaire to rate the degree to which various aspects of the job were problematic. Second, the supervisors used the JDLC II (Job Design for the Life Cycle), a structured job evaluation questionnaire, based on interviews with operators at quality circle meetings. Third, an industrial engineer and the general affairs manager performed analyses using JDLC I, a more complex version of JDLC II. Finally, the I.E. and general affairs manager viewed video tapes of selected jobs to analyze the amount of time spent in each of nine working postures (for 24 of the jobs).

All data were analyzed by an industrial engineer, who had been trained along with the steering committee and given personal tutoring by the consultant. He quickly became skilled at using each of the four data collection and analysis methods above. Ideas for redesign came partly from the quality circles, but most redesign was handled by industrial engineering. All data and suggestions for redesign were presented to the steering committee for discussion and final approval.

\section{Mitsubishi}

The structure of the program at Mitsubishi appears on the surface virtually identical to that of Daikin (see Fig. 4), but the scope was many times larger and the actual division of labor somewhat different.

Mitsubishi designed their ergonomics program to cover most of the plant from the start. Like Daikin, they formed a steering committee led by the Director of General Affairs. The steering committee was trained in working posture analysis which was the focus of the ergonomics effort. After working with selected safety circles on a small number of cases, this committee developed a training program based on an internally written training manual. The steering committee met monthly for the first year of the program and then held update meetings 15 times over the next five years.

All production supervisors were trained in posture analysis based on the nine-posture system

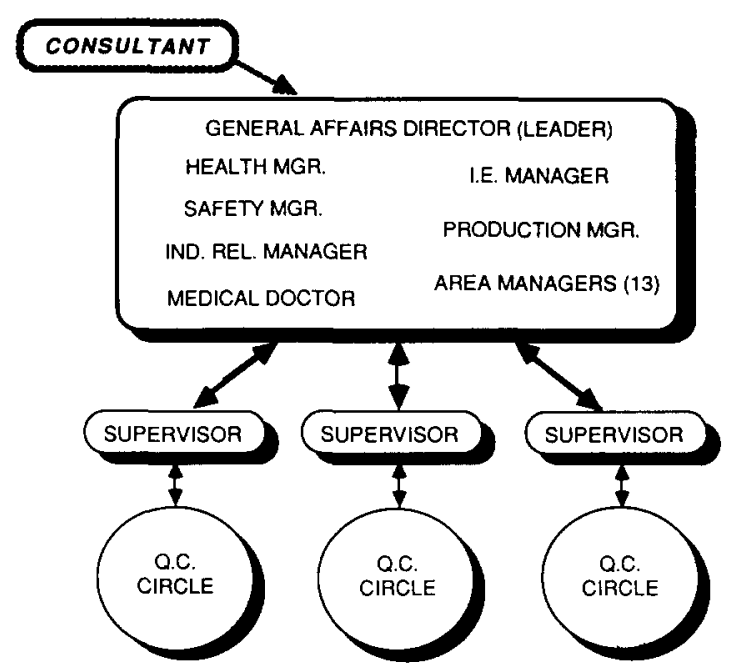

Fig. 4. Mitsubishi engine plant ergonomic program.

developed by Nagamachi (1981, in press) and they in turn trained their direct reports, members of their safety circles. Safety circle members estimated the proportion of time they spent in each of the nine postures and this was used as a basis for redesigning problematic jobs. Most of the redesign was done in safety circle meetings led by the supervisor. Supervisors then presented proposed solutions to their area manager who presented them for approval to the steering committee. Small changes could be made by circle members themselves without higher approval. Any large changes involving design of major pieces of equipment were handled by industrial engineering (there were only four such cases out of 900 job changes).

\section{Program process}

A comparison of ergonomic design processes used in the U.S. and Japanese programs shows very different approaches to "participatory" practices. Figure 5 summarizes the roles of various individuals and groups in the four plants. Again, the two U.S. plants are grouped as their processes were virtually identical.

First, consider the role of individual compared to group effort. In the U.S., the multi-functional, and multi-level ergonomics teams had a strong role in every step of the ergonomics design process (with the exception of the more technically complex objective job analysis run by the university 


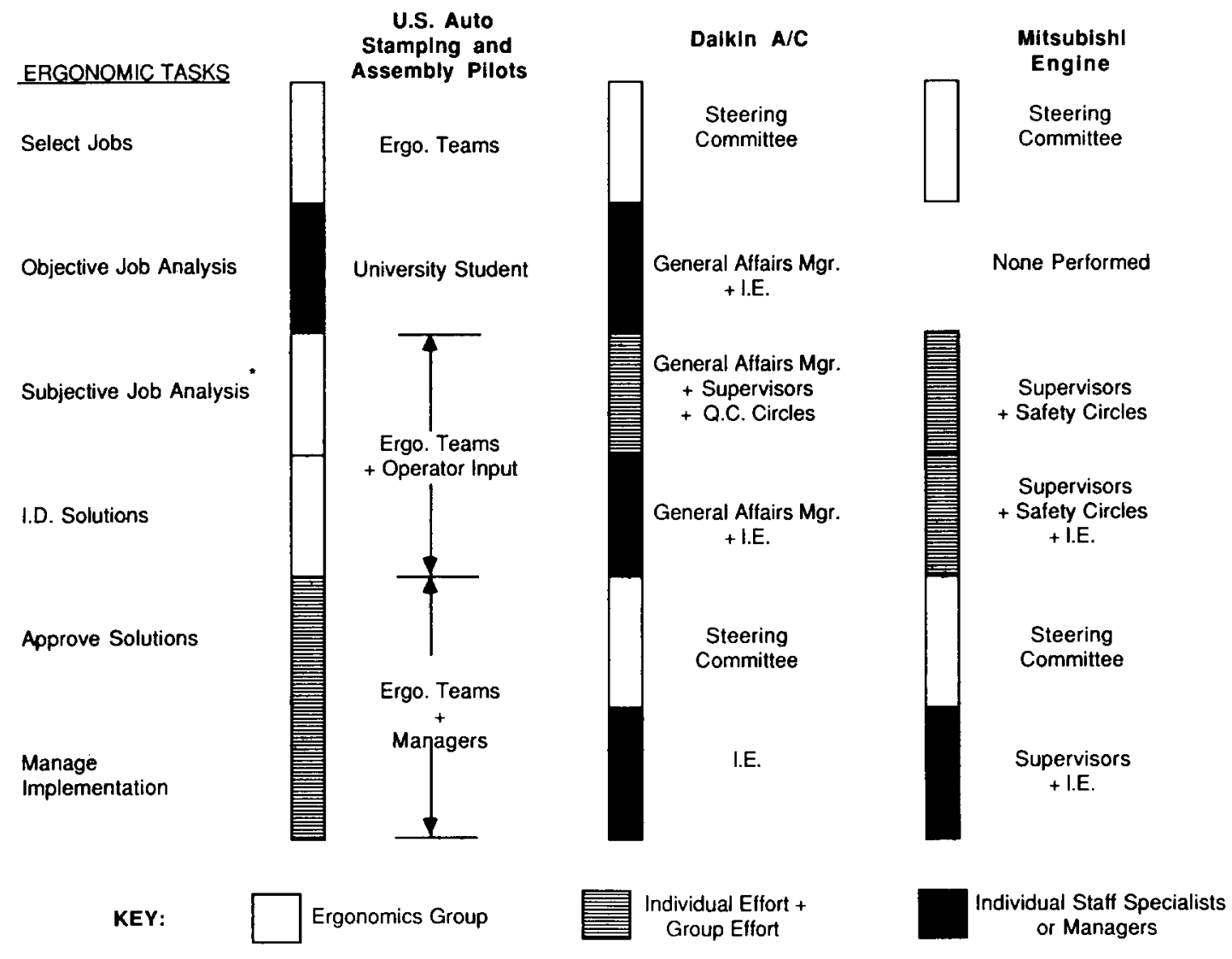

* In the second year of the U.S. assembly plant program, responsibility was given to each committee member to review jobs outside of meeting time and report their observalions to the groups. This greatly accelerated the process of job analysis.

Fig. 5. Ergonomic design process in the U.S. and Japan plants.

student). Even approving solutions and monitoring implementation were handled mainly by these groups.

By contrast to the U.S. cases, the Japanese companies had a more explicit division of labor between different individuals and groups at different levels of the organization. The Daikin plant was most heavily dependent on individual effort at the middle management and staff level, outside of group meetings. The steering committee guided the process through planning and decision-making, the general affairs manager and I.E. performed technical analyses, redesigned the jobs, and monitored implementation. The main role of the supervisors and quality circles was to provide data to the general affairs manager and I.E.

The Mitsubishi plant was the most heavily dependent on the direct involvement of workers and

TABLE 1

Outcomes of the participatory ergonomics programs

\begin{tabular}{lcccc}
\hline & $\begin{array}{l}\text { U.S. auto } \\
\text { stamping }\end{array}$ & $\begin{array}{l}\text { U.S. auto } \\
\text { assembly }\end{array}$ & $\begin{array}{l}\text { Daikin } \\
\text { air conditioning }\end{array}$ & $\begin{array}{l}\text { Mitsubishi } \\
\text { engine }\end{array}$ \\
\hline Period observed & $6 / 85-11 / 87$ & $8 / 86-11 / 87$ & $5 / 82-8 / 82$ & $6 / 82-8 / 87$ \\
Number of months & 29 months & 16 months & 4 months & 50 months \\
Number of redesign projects & 79 & 112 & 14 & 900 \\
Redesign projects/month & 2.7 & 7 & 3.5 & 18 \\
\hline
\end{tabular}


their supervisors. While planning and final approval was handed by the steering committee, most analysis and redesign came from the safety circles themselves. However, implementation was managed by supervisors and industrial engineers, with little direct involvement of the safety circles.

Second, consider the role of worker participation in these cases. In terms of the typology of participative approaches described earlier, the U.S. plants used a combination of direct involvement of worker representatives (those selected for the ergonomics teams) in consensus decision-making (Model V) and individual consultation with operators of jobs being redesigned (Model II). Daikin used direct consultation with quality circles (Model IV) mainly for subjective job analysis. Finally, only Mitsubishi used some direct group consensus (Model VI), though with a strong role for the supervisor who served as the link between the safety circles, the steering committee, and industrial engineering.

In sum, the U.S. plants depended most heavily on group problem-solving for all stages of the ergonomic design process, though workers whose jobs were redesigned had a voice only indirectly through a representative or directly in a consultative mode. The Japanese plants relied on input from all workers involved through the mechanism of quality/safety circles, though this was in a purely consultative mode at Daikin and was channeled through the first-line supervisors at both plants. In both Japanese plants there was a highly structured division of labor between groups and individuals, management and workers, and staff and line.

\section{Program outcomes}

Outcomes of the programs in terms of numbers of "redesign projects" per month are shown in Table 1. All changes were made to improve posture, reduce fatique, or in some other way reduce physical stress. They were all based on ergonomic evaluations using the concepts and tools covered in training. In most cases multiple changes were made to a single job or, far less frequently, a single type of change (e.g., the same tool change for twenty jobs) was made to multiple jobs. We counted each case as one "redesign project." Thus, each redesign project involved the complete design process, from selection to analysis to solution development to implementation.

One might argue that counting changes to jobs is not meaningful as the changes may not be ergonomically sound. Quantitative evaluations (using ergonomics analysis techniques) of ten redesign projects, before and after the changes, in the U.S. Stamping plant (Liker et al., in press) and all of the redesign projects in the Daikin plant (Nagamachi, 1983) showed that all jobs had been improved on at least one dimension (e.g., energy expenditure, back stress, posture). In no cases examined were jobs made more stressful on any dimension. In the case of Mitsubishi, analysis was only done before the charges were made. The first 224 redesign projects are summarized by Nagamachi (in press). The most common causes of bad posture were due to handling heavy parts (37\%), inadequate table height (25\%), and poor working position relative to the equipment (14\%). Common solutions included redesigning the tables, some form of automation, changing the height of instrument gauges, and adding hoists.

By far, Mitsubishi made the greatest number of job changes per month (averaged across the four years of the program). By using safety circles, they mobilized a large number of problem solving groups (approximately 100) whose output naturally exceeded that of the few teams at the other plants. This is not to say they were more productive. We do not know the actual output per person-hour of time invested in the program.

Daikin's changes per month fall between the two U.S. cases. However, what is impressive about Daikin is the speed of their start-up and implementation. Their 14 jobs were analyzed, redesigned, and implemented literally during the first 3.5 months of the ergonomics program. All of the changes were made by outside vendors during one week in August when the plant was shut down. Moreover, they had analyzed about twice this number of jobs, concluding only these 14 warranted ergonomic redesign. While Mitsubishi chose to focus on only one dimension for evaluation and redesign, that of posture, Daikin was able to use a comprehensive battery of analysis techniques due to the knowledge and skill of their industrial engineer and general affairs manager.

The U.S. cases took 4-5 months in training and organizational meetings before even getting off the 
ground. In a fraction of this time, the Japanese programs were launched and operating. However, the greater emphasis on preparation of the U.S. plants may have been necessary to the success of the group approach used by these teams in all phases of problem solving and decision making. The relatively high rate of job changes in the auto assembly plant may have had something to do with the fact that the area managers led the teams, hence assuring prompt follow-through by team members and the skilled trades who implemented job changes. The U.S. plants used the most technically sophisticated job analysis procedures, though these were run exclusively by the university students assigned to the committee.

\section{Summary of similarities and differences}

Key features of the programs are summarized in Table 2. The programs were similar in a number of ways:

1. All four were considered successful pilot programs by their companies so that they were getting a particularly high level of attention and resources.

2. All four plants had strong existing employee participation programs (by their company's standards) in which employees met in small groups to solve problems.

3. The focal point of all four programs was an ergonomics committee including representation from a variety of functions (e.g., engineering, safety, medical, industrial relations, the union, production management, etc.).

4. All four programs led to changes in a significant number of jobs and limited external evaluation suggests these were ergonomically sound changes.

5. While these programs used a participative or "team" approach, there was a judicious blending of individual and group effort in all four cases. In each case leaders were appointed or emerged who took responsibility for learning to use ergonomics analysis tools, running meetings, and expediting ergonomic changes.

The U.S. programs were also different from the Japanese programs in significant ways:

1. Program initiation. A concerted effort was made in the U.S. plants to involve the auto industry union (U.A.W.) as a full partner in the program, while in Japan the company unions were informed, in Mitsubishi, and involved, in Daikin, at a relatively low level and with little special effort.

2. Training. The University was a major driving force in the U.S. programs. For example, in the U.S. plants a graduate student was assigned to meet weekly with committees throughout the program and serve as the ergonomics expert. By contrast, the Japanese plants were much more self-sufficient, developing their own technical expertise and using their consultant for initial training and occasional advice.

3. Program structure. Despite the usual characterization of Japanese management as being more "participative" than the U.S., the Japanese programs were more hierarchical than the U.S. programs. The Japanese ergonomics committee was a high-level plant-wide committee, decisions were top down, ideas were bottom up, the chain of command was observed faithfully (e.g., via production supervisors), and specialized staff functions were used extensively for training, analysis, and implementation. Hourly worker input was obtained via the production supervisor who led their quality circles. By contrast, the ergonomics committees in the U.S. programs were decentralized (in specific areas), included shop-level union representatives, production worker representatives, and often production workers were invited directly to meetings.

4. Worker participation. The U.S. plants intentionally steered clear of mixing ergonomics with their existing participative programs, while the Japanese plants used existing employee problemsolving groups to work on ergonomics. This was particularly effective at Mitsubishi as they already had established "safety circles".

5. Analysis tools. The ergonomics technology used in the Japanese firms for evaluating jobs, particularly in Mitsubishi, was based more on qualitative judgements than the U.S. technology, therefore enabling the plants to be more self-sufficient in the analysis stage and use more broad participation in job analysis. In the case of Mitsubishi, the plant chose to focus their program on reducing fatigue through improvements in working posture (Nagamachi, in piess). Estimates of time spend in each of eight postures (from desired neutral to awkward) was the only analysis 
TABLE 2

Summary description of participatory ergonomics programs in four plants

\begin{tabular}{|c|c|c|c|c|}
\hline & U.S. Stamping & U.S. Assembly & Daikin & Mitsubishi \\
\hline$\overline{\text { Purpose }}$ & $\begin{array}{l}\text { Improve quality of } \\
\text { work life (QWL) }\end{array}$ & $\begin{array}{l}\text { Lower medical } \\
\text { costs, raise } \\
\text { productivity, } \\
\text { improve QWL }\end{array}$ & $\begin{array}{l}\text { Job security for } \\
\text { senior workers, } \\
\text { increase productivity }\end{array}$ & Reduce fatigue \\
\hline $\begin{array}{l}\text { Program } \\
\text { Initiation }\end{array}$ & \multicolumn{2}{|c|}{$\begin{array}{l}\text { Division-level contract with university, } \\
\text { University-plant negotiation, } \\
\text { Involve union, } \\
\text { invite worker participants }\end{array}$} & $\begin{array}{l}\text { Dept. labor-university } \\
\text { contract, university-plant } \\
\text { negotiation, } \\
\text { Involve union }\end{array}$ & $\begin{array}{l}\text { Plant hires consultant, } \\
\text { Union permission, } \\
\text { Plant-wide meeting }\end{array}$ \\
\hline Training & \multicolumn{2}{|c|}{$\begin{array}{l}\text { Multiple university training courses }+ \\
\text { ongoing training by graduate student }\end{array}$} & $\begin{array}{l}\text { 2-day training for } \\
\text { steering and plant staff }\end{array}$ & $\begin{array}{l}\text { Consultant trains trainers, } \\
\text { Trainers train } 50 \text { area mgrs. }+ \\
150 \text { supervisors, } \\
\text { Supervisors then train circles }\end{array}$ \\
\hline $\begin{array}{l}\text { Program } \\
\text { Structure }\end{array}$ & $\begin{array}{l}\text { Steering comm. }+ \\
\text { area ergo. comms. }\end{array}$ & $\begin{array}{l}\text { Area. ergo. } \\
\text { comms. }\end{array}$ & $\begin{array}{l}\text { Steering comm. - approves } \\
\text { Staff do all tech. work } \\
\text { Q.C. circles provide data } \\
\text { and suggestions }\end{array}$ & $\begin{array}{l}\text { Steering comm. - approves, } \\
\text { Area managers manage, } \\
\text { Plant staff design equipment, } \\
\text { Supervisors train/lead, } \\
\text { Safety circles provide data/ } \\
\text { suggestions }\end{array}$ \\
\hline $\begin{array}{l}\text { Worker } \\
\text { Participation }\end{array}$ & \multicolumn{2}{|c|}{$\begin{array}{l}\text { Hourly representatives on ergo. } \\
\text { committees + operators invited } \\
\text { to meetings }\end{array}$} & $\begin{array}{l}\text { Q.C. circles } \\
\text { provide data }+ \\
\text { suggestions }\end{array}$ & $\begin{array}{l}\text { Safety circles } \\
\text { provide data }+ \\
\text { suggestions }\end{array}$ \\
\hline $\begin{array}{l}\text { Analysis } \\
\text { Tools }\end{array}$ & \multicolumn{2}{|c|}{$\begin{array}{l}\text { 2D static strength, } \\
\text { Energy expenditure, } \\
\text { Posture analysis program, } \\
\text { Checklists (designed by each plant) }\end{array}$} & $\begin{array}{l}\text { JDLC } 1 \& 2 \text {, } \\
\text { Posture analysis, } \\
\text { Stress questionnaire }\end{array}$ & Posture analysis \\
\hline $\begin{array}{l}\text { Implemen- } \\
\text { tation } \\
\text { Resources }\end{array}$ & \multicolumn{2}{|c|}{$\begin{array}{l}\text { Project-by-project funding }+ \\
\text { Internal skilled trades }+ \text { Limited use } \\
\text { of outside contractors }\end{array}$} & $\begin{array}{l}\text { Dept. of labor funding }+ \\
\text { Internal budget set up for } \\
\text { equip. + Outside contractors }\end{array}$ & $\begin{array}{l}\text { Project-by-project funding }+ \\
\text { Changes by circles }+ \\
\text { Internal skilled trades }+ \\
\text { Outside contractors }\end{array}$ \\
\hline
\end{tabular}

procedure. Thus, supervisors could be trained easily in the technology. The Daikin group used a broader set of analysis methods, but the two Job Design for the Life Cycle methods (JDLC 1\&2) and the stress questionnaire were all based on worker assessments of their work situation. The U.S. plants also relied on judgements by committee members for most of their analysis (guided by checklists), but used computer software for quantifying specific problems which was run exclusively by a university student.

6. Implementation resources. Daikin organized their program, analyzed a complete production line, and made changes to every job in a two-week shut down period. Mitsubishi was able to change a phenomenal number of jobs in four years using internal labor, contract labor, and the safety circles themselves. Implementation seemed to be more of a barrier in the U.S. plants who relied primarily on internal skilled trades to perform the labor.

\section{CONCLUSIONS}

There were clear similarities between the two Japanese programs and the two U.S. programs, and clear differences across countries. There were too many differences across plants and nations to make strong claims about the cause of these differences. For example, were the differences due to culture or were they due to the different approaches of the consultants in each country? We have argued that the actual program structures were determined by the plants, but not without 
some influence of the consultants. Nonetheless, we feel some conclusions can be drawn from these cases.

First, a participative approach to ergonomics can work in very different contexts using different approaches. In all four plants a significant number of jobs were changed. In the two U.S. plants and in Mitsubishi, the program had significant staying power. After several years in operation, groups were still meeting and using ergonomics methods to improve jobs. Each plant used different categories of personnel for their programs and there were different approaches to worker participation. Rather than argue one approach was true worker participation and others were not, we suggest that each approach is appropriate in the right context.

Second, there may be a trade-off between technical sophistication of ergonomics analysis tools and the ability of plants to use broad participation and remain technically self-sufficient. More complex technology means more heavy reliance on outside experts. Mitsubishi was able to proceed with a minimum of training of quality circle members because they focused only on posture using a very simply analysis procedure. Daikin used more sophisticated analysis methods, but relied on a few technical experts in the plant to execute these analyses-quality circle members were less directly involved in decision-making compared to Mitsubishi. The U.S. plants used the most complex analysis tools and only worker representatives truly participated in consensus decision making. These representatives were given special training for their role, training which was not given to operators invited to meetings to express their opinions on changes to their job. Moreover, all complicated quantitative analyses in the U.S. plants were performed by a graduate student on loan from the university.

Third, there do appear to be cross-national differences that influenced the design and implementation of the ergonomics programs across U.S. and Japanese plants.

One notable difference is the role of existing employee problem-solving groups across countries. U.S. employee participation programs are typically part of an attempt to transform the labor relations climate from one based on adversarial relations to a joint partnership between labor and management. As such, the program purports to give power, influence, and dignity to hourly employees who for decades were treated as a pair of hands. This includes the power to set their own agendas as problem solving groups. Management treads lightly when it comes to upsetting the delegate balance that exists between reverting to the old autocratic climate and gaining labor's trust that the new "participative" climate is real and stable. Management in both U.S. plants in this study flatly refused to mix the ergonomics program with their existing program of employee problem-solving groups. They felt the groups had their own heavy agendas and to impose ergonomics on them would be contrary to the voluntaristic philosophy of the programs.

In contrast, Japanese managers had no hesitation about using their quality circles (or safety circles) for ergonomics. Japan's quality circles were established in a cooperative labor relations climate. The unions are enterprise unions rather than industry unions and there is little of the tension that exists in the U.S. (Cole, 1979). Japanese quality circles were established to improve quality, not to transform the management climate. Participation is considered an employee moral obligation to the company, not a voluntaristic activity - the virtual $100 \%$ participation rate in both Japanese companies illustrates this point. Moreover, it is quite common for management to "suggest" to employees that they work on specific problems. For example, Cole (1979, p. 201) writes about the highly publicized job redesign of the Toyota auto body shop:

"...the emphasis is not on participation per se, but rather on achieving the consent of workers for policies which management wants to pursue, as well as guiding workers in the direction in which management would like to see them move...we have here a carefully controlled participation in which management often takes the lead informally or formally in initiating policies that workers are then guided to accept and pursue."

The participatory ergonomics programs in Japan examplified this "carefully controlled participation". At Daikin, the workers were mainly a source of data. In Mitsubishi they contributed ideas for solutions as well as occasionally even implemented simple changes; however, the responsibility was in the hands of the supervisor.

A second major difference across countries was the role of the first-line supervisor. In the U.S. 
plants the supervisor had no formal involvement in the ergonomics program and no training in ergonomics. He or she was occassionally invited to meetings and informed when one of their jobs was to be worked on. Indeed, there was greater effort to get the input of the operator to maintain the participative climate. The usurping of the traditional power of the first-line supervisor has been a major obstacle in employee participation programs in U.S. plants (Kanter, 1983; Hackman and Oldham, 1980). By contast, the supervisor played a central role in the Japanese participatory ergonomics programs. Cole $(1979$, p. 210$)$ also observed this trend in the Toyota auto body shop and noted that when they shifted to a more "participative" work team concept the supervisor's role was actually strengthened:

“...Management's idea was that by strengthening the role of the foreman through shifting many functions previously carried out in the personnel department to the shop level, they would be able to increase worker participation. This is because the foreman can more effectively absorb the ideas of subordinates than can distant functionaries. In short, there appears to be no conflict between increasing worker participation and the strengthening of the foreman role. The Japanese brand of worker participation clearly relies on principles of hierarchical control." (italics added)

Fourth, none of the programs relied exclusively on direct participation of all hourly employees in consensus decision making. Rather, each of the models were some blend of models I-V described earlier in the paper. The expertise required for ergonomics is sufficiently complex that it may be impractical to expect workers throughout a plant to analyze and redesign their own jobs without assistance from personnel, medical, and engineering staffs. Mitsubishi came closest to accomplishing this, but was able to do so by limiting their analysis to posture.

Finally, we believe that the approach needs to be adapted to the context-it cannot be simply copied. There were some differences between countries that reflect the different structure and culture of industry across nations, and there were differences in programs across companies within country. We do not believe any of the programs could have simply been transferred unmodified to another company.

\section{ACKNOWLEDGEMENTS}

We gratefully acknowledge the assistance of the many people at Ford, Mitsubishi, and Daikin who made their ergonomics programs a success and generously shared information with us about those programs. We also thank Don Chaffin, Andy Imada, Robert Cole, and Sheryl Ulin who provided useful comments on an earlier draft of this paper.

\section{REFERENCES}

Armstrong, T.J., Radwin, R.G., Hansen, D.J., Kennedy, K.W., Afamrl/Heg, 1986. Repetitive trauma disorders: Job evaluation and design. Hum. Factors, 28(3): 325-336.

Chaffin, D. and Andersson, G., 1984. Occupational Biochemanics. John Wiley \& Sons, NY

Chaffin, D. and Baker, W.H., 1970. A biomechanical model for analysis of symmetric sagittal plane lifting. AIIE Trans., 2(1): $16-27$

Coch, L. and French, J., 1948. Overcoming resistance to change. Hum. Relat., 512-532.

Cole, R., 1979. Work, Mobility, and Participation. University of California Press, Berkeley, CA.

French, W.L. and Bell, C.H., 1987. A brief history of organization development. J. Contemp. Bus., Summer: 1-8.

Garg, A., Chaffin, D. and Herrin, G., 1978. Prediction of metabolic rates for manual materials handling jobs. Amer. Ind. Hyg. Assoc. J., (39): 661-673.

Hackman, J.R. and Oldham, G.R., 1980. Work Redesign, Addison-Wesley, MA.

Hull, F., Azumi, K. and Wharton, R., 1988. Suggestion rates and sociotechnical systems in Japanese versus American factories: Beyond quality circles. IEEE Trans. Eng. Manage., 35(1): 11-24.

Imada, A. (Ed.), in press. Participatory Ergonomics, Taylor \& Francis, London.

Juran, J.M., 1967. The QC circle phenomenon. Ind. Qual. Control, January: $15-22$.

Ishikawa, K., 1968. QC Circle Activities. Union of Japanese Scientists and Engineers, Tokyo, Japan.

Kanter, R.M., 1983. The Change Masters. Simon and Schuster, NY.

Liker, J., Joseph, B. and Ulin, S., in press. Participatory ergonomics in two U.S. automotive plants. In: A. Imada (Ed.), Participatory Ergonomics. Taylor \& Francis, London.

Locke, E., Schweiger, D. and Latham, G., 1986. Participation in decision making: When should it be used? Organ. Dyn., Winter: $65-79$.

Nagamachi, M., in press. Application of participatory ergonomics through quality circle activities. In: A. Imada (Ed.), Participatory Ergonomics, Taylor \& Francis, London. 
Nagamachi, M., 1983. Job Redesign in Daikin, Japan Department of Labor.

Nagamachi, M., 1981. Job Design for the Life Cycle. Japan Production Center, Tokyo.

NIOSH, March 1981. Work Practices Guide for Manual Lifting. U.S. Department of Health and Human Services.
Rogers, E.M., 1983. Diffusion of Innovations. The Free Press, NY.

Sashkin, M., 1986. Participative management remains an ethical imperative. Org. Dyn., Spring: 62-75.

Vroom, V.H. and Yetton, P.W., 1973. Leadership and Decision Making, University of Pitssburgh Press, PA. 